\title{
PENGEMBANGAN MODEL PEMBELAJARAN TEMATIK INTEGRATIF BERBASIS PROYEK DALAM MENERAPKAN PENDIDIKAN KELAUTAN PADA ANAK DI KEPULAUAN SERIBU
}

\author{
HAPIDIN ${ }^{1}$, NURJANNAH ${ }^{2}$, SOFIA HARTATI ${ }^{3}$ \\ Fakultas Ilmu Pendidikan, Universitas Negeri Jakarta \\ Email: hapidin1964@gmail.com
}

\begin{abstract}
ABSTRAK
Education is one way to prepare the next generation of quality nations. The magnitude of the marine territory of Indonesia must be balanced with the next generation who have high marine life. This is in contrast to the fact that the people of Untung Jawa island have not shown their concern and care to provide targeted marine education as a form of social responsibility in preparing the maritime generation in its territory, the school education institution (especially $S D$ Negeri Untungjawa) has not been structured and programmed to provide marine education as part of the implementation of the Curriculum 2013, especially on curriculum diversification in accordance with geographical conditions, advantages and disadvantages of the institution. This research is an $R \& D$ research that aims to develop an integrative thematic model of project-based learning in implementing maritime education on elementary school students in the Thousand Islands, DKI Jakarta. This project-based integrative thematic conceptual learning model is expected to be an alternative and contribute to implement marine education from an early years.
\end{abstract}

Key Word: Integrative thematic learning, project learning, marine education

Pendidikan menjadi salah satu cara untuk mempersiapkan generasi penerus bangsa yang berkualitas. Besarnya wilayah kelautan Indonesia harus diimbangi dengan generasi penerus yang memiliki jiwa kelautan yang tinggi. Hal ini bertolak belakang dengan fakta yaitu warga masyarakat pulau Untung Jawa belum ada yang menunjukkan perhatian dan kepeduliannya untuk memberikan pendidikan kelautan yang terarah sebagai bentuk tanggung jawab sosial dalam mempersiapkan generasi maritim di wilayahnya, lembaga pendidikan sekolah (khususnya SD Negeri Untungjawa) belum secara terstruktur dan terprogram memberikan pendidikan kelautan sebagai bagian dari pelaksanaan Kurikulum 2013, terutama pada diversifikasi kurikulum sesuai kondisi geografis, keunggulan dan kelemahan yang dimiliki lembaga. Penelitian ini merupakan penelitian R\&D yang bertujuan untuk mengembangkan model pembelajaran tematik integratif berbasis proyek dalam mengimplementasikan pendidikan kelautan pada siswa SD kelas awal di kepulauan Seribu, DKI Jakarta. Model konseptual pembelajaran tematik integratif berbasis proyek ini diharapkan dapat dijadikan alternatif dan memberikan kontribusi untuk mengimplementasikan pendidikan kelautan sejak usia dini.

Kata Kunci: Pembelajaran tematik integratif, proyek, pendidikan kelautan. 


\section{PENDAHULUAN}

Pembelajaran tematik integratif merupakan salah satu kebijakan konsep dan implementasi kurikulum yang telah digagas sejak kurikulum berbasis kompetensi (KBK) pada tahun 2004. (Depdiknas, 2003) Khususnya untuk Sekolah Dasar (SD) atau Madrasah Ibtidaiyah (MI). Kebijakan tersebut telah disempurnakan melalui peraturan pemerintah nomor 19 tahun 2005 tentang standar nasional pendidikan (SNP) dan peraturan menteri pendidikan nasional nomor 41 tahun 2007 tentang standar proses yang meneguhkan tentang pentingnya pembelajaran pembelajaran tematik integratif untuk pendidikan di SD (Permendiknas, 2005).

Pada tahun 2013, kebijakan tersebut mengalami revisi dan penyempurnaan melalui kurikulum 2013 (K-13) yang secara prinsip tetap mengusung esensi pembelajaran tematik integratif untuk SD.

Pada tahapan implementasi, pelaksanaan Kurikulum Tingkat Satuan Pendidikan maupun K-13 pada pelaksanaan pembelajaran tematik integratif untuk SD masih banyak menemui kendala dan masalah

Hasil studi literatur yang dilakukan oleh Sukini (2012) mengemukakan bahwa (1) Guru masih kurang memahami langkah-langkah melakukan pemetaan KD dengan tema dari beberapa mata pelajaran terkait, (2) Guru masih kurang memahami perancangan pembelajaran yang berupa penyusunan silabus dan RPP (Rencana Pelaksanaan Pembelajaran) dengan menggunakan pendekatan tematik, (3) Guru belum dapat menyampaikan pembelajaran tematik. Pembelajaran yang disampaikan masih terkotak kotak dalam berbagai mata pelajaran yang ditematikkan, dan (4) Guru belum mampu menyusun instrumen penilaian untuk pembelajaran tematik

Fakta ini memperkuat betapa lemah sosialisasi dan pemahaman konsep dan implementasi pembelajaran tematik integratif dilaksanakan di SD Negeri. Fakta tersebut juga dapat menjadi kegagalan yang berulang dalam pelaksanaan kebijakan kurikulum 2013, khususnya dalam melaksanakan pembelajaran 
tematik integratif di SD sebagai bagian dari kajian usia dini.

Kondisi faktual tersebut juga diperkuat oleh hasil penelitian Irene di SD Negeri Balekerto Magelang, pada 3 guru kelas rendah, menemukan beberapa kesimpulan lemahnya kemampuan guru dalam melaksanakan pembelajaran tematik. (Irene, 2013) Temuan yang dimaksud diantaranya adalah (1) guru belum mampu menerapkan pelaksanaan pembelajaran tematik dalam RPP mereka, (2) guru masih melaksanakan pembelajaran secara parsial atau terpisah-pisah dan (3) guru belum melaksanakan penilaian dengan menggunakan tematik.

Penelitian yang dilakukan oleh Sulistiani dan Arya menemukan latar permasalahan mengenai kondisi atau lingkungan PAUD Bahagia adalah wilayah pesisir, namun pengenalan akan laut berserta isinya masih belum maksimal. Pada pengembangan tematema pembelajaran, masih ditemukan kurangnya pemahaman guru dalam mengembangkan sub tema yang sesuai dengan kondisi sekolah. Disamping itu, guru juga masih bingung menghubungkan tema dengan sub indikator (dari hasil dan kompetensi dasar) bidang pengembangan. Pelaksanaan evaluasi pembelajaran masih belum dilaksanakan secara berkesinambungan. (Sulistiani dan Arya, 2014)

$\begin{array}{rccc}\text { Sebagaimana } & \text { studi } & \text { yang } \\ \text { dilakukan oleh } & \text { Haji } & \text { yang }\end{array}$ menyimpulkan terdapat peningkatan hasil belajar sebesar $79,09 \%$ pada kelompok siswa SD yang melaksanakan pembelajaran tematik dibandingkan dengan siswa yang memperoleh pembelajaran konvensional sebesar 54,615\%.

Kondisi tersebut mendorong perlunya inovasi pengembangam model pembelajaran tematik integratif untuk SD Negeri. Penelitian ini akan difokuskan pada pengembangan model inovasi model pembelajaran tematik integratif berbasis proyek. Inovasi model pembelajaran ini diharapkan akan menjadi solusi untuk mengimplementasikan pembelajaran tematik integratif, khususnya pengintegrasian dengan penerapan pendidikan kelautan pada siswa SD.

Kondisi faktual dan geografis kelautan akan menjadi tema sentral dan utama dalam mengembangkan 
model pembelajaran tematik integratif proyek. Kajian ini sejalan dengan Rencana Induk Riset Nasional (RIRN) yang memberikan salah satu prioritas pada penelitian kemaritiman (kemenristek, 2017) Pengembangan model pendidikan kelautan sebagai hasil dari penelitian ini diharapkan akan membantu pemerintah dalam membangun budaya maritim generasi muda Indonesia yang memiliki kesiapan untuk mewujudkan Indonesia sebagai poros maritim dunia.

Selain kondisi masalah pembelajaran tematik integratif di SD yang telah dikemukakan di atas, fokus utama penelitian akan ditujukan pada "Bagaimana merancang pengembangan model pembelajaran tematik integratif berbasis proyek dalam mengimplementasikan pendidikan kelautan pada siswa SD kelas Awal SD Negeri Satap Pulau Untungjawa, Kepulauan Seribu, DKI Jakarta?'. Berdasarkan fokus utama tersebut dijabarkan beberapa sub fokus penelitian sebagai berikut :

1. Bagaimana kondisi pelaksanaan pembelajaran tematik integratif pada SD kelas awal?
2. Bagaimanakah proses pengembangan model pembelajaran tematik-integratif berbasis proyek yang dapat mengimplementasikan pendidikan kelautan pada peserta didik SD Kelas Awal?

3. Apakah model pembelajaran tematik integratif berbasis proyek dapat meningkatkan meningkatkan Pendidikan kelautan pada Anak SD kelas awal?

\section{KAJIAN TEORITIK}

Pendidikan kelautan merupakan suatu keniscayaan yang harus dijadikan fokus kebijakan dan implementasi pendidikan untuk mempersiapkan generasi maritim sejak usia dini dan sekolah dasar kelas awal. Kebijakan ini menjadi isu strategis dan seharusnya menjadi program strategik jika pemerintah bersungguh sungguh dalam mewujudkan Indonesia sebagai poros maritim dunia.

Konsep dan implementasi pendidikan kelautan akan membantu mempersiapkan generasi kelautan. Proses pembelajaran tematik mengintegrasikan substansi 
dan kompetensi mata pelajaran dengan konteks kelautan sebagai konten maupun sumber belajar pada kelas awal Sekolah Dasar.

Penelitian implementasi pendidikan kelautan termasuk fokus kajian yang paling langka dan sangat sulit untuk ditemukan di karenakan metodologi penelitian yang berkaitan dengan kelautan cukup sulit dilakukan. Seperti halnya yang kemukakan oleh Stepart yang mengungkapkan bahwa:

Since marine education is a unique interdisciplinary field, research methodologies are sometimes difficult to bring together and actuate because they originate in different disciplines

Studi maritim (kelautan) yang cukup relevan dilakukan oleh Suryani dkk. (2004) yang menyimpulkan bahwa sebaran tingkat pendidikan anak nelayan di desa Karangjaladri secara umum berada pada kategori tingkat pendidikan rendah sebesar $70 \%$. Kondisi ini memberikan gambaran bahwa ada dugaan tingkat pendidikan yang rendah tersebut berkorelasi dengan orientasi dan aspirasi pendidikan kaum nelayan yang justru lebih banyak pada orientasi kehidupan di daratan dibandingkan dengan kehidupan di lautan.

Oleh karena itu, konsep dan implementasi pendidikan kelautan menjadi salah satu pemikiran utama yang menjadi kajian dalam penelitian ini. Dalam menyusun konsep dan implementasi pendidikan kelauatan, peneliti akan memulai dengan pengembangan model pembelajaran tematik integratif yang dipadukan dengan pembelajaran proyek menjadi model pembelajaran tematik integratif berbasis proyek. Penelitian pengembangan model ini diharapkan akan menjadi solusi untuk menemukan inovasi pembelajaran pada pendidikan SD dan sekaligus membangun pemikiran, konsep dan penerapan urgensi pendidikan kelautan sebagai salah satu bagian utama dari bahan kebijakan pembaharuan kurikulum dan pendidikan di Indonesia. Pengembangan model ini selanjutnya diharapkan akan menyediakan ruang pemikiran dan 
praktik inovatif dalam menyediakan konsep serta implementasi pendidikan kelautan yang dilaksanakan melalui model pembelajaran tematik integratif berbasis proyek.

\section{METODE PENELITIAN}

Penelitian ini menggunakan metode penelitian dan pengembangan model (R\&D) model Borg and Gall. Dalam metode penelitian dan pengembangan memungkinkan peneliti untuk melakukan justifikasi empirik dengan mengggunakan statistik untuk melakukan validasi empirik terhadap instrumen penelitian yang dipergunakan. Selain itu, penggunaan metode penelitian ini juga memungkinkan penelitian melakukan pendekatan naturalistik terhadap proses berlangsungnya penggunaan model untuk menelaah, menggambarkan serta menemukan perasaan, pemahaman, keyakinan dan pandangan dari subjek tentang berbagai hal. Melalui penggunaan dua pendekatan dalam analisis data tersebut diharapkan akan membantu memberikan berbagai temuan yang bermakna, akurat serta dapat dipertanggung jawabkan.

\section{HASIL DAN PEMBAHASAN}

SD Negeri Pulau Untungjawa merupakan satu-satunya sekolah dasar yang ada di kelurahan Pulau Untungjawa, Kecamatan Kepulauan Seribu Selatan, Kabupaten Kepulauan Seribu, DKI Jakarta. Berdasarkan dokumen kelurahan tercatat ada 210 nelayan $(45,6 \%)$ dari total kepala keluarga sebanyak 461 orang. (Data kependudukan Kelurahan Pulau Untung Jawa)

Data ini cukup berbeda dengan kenyataan yang ditemukan bahwa status nelayan pada kartu keluarga belum pasti secara nyata melakukan pekerjaan nelayan. Dari 210 status nelayan diperkirakan hanya $15 \%$ saja yang menjalankan profesi nelayan (harian atau mingguan). Sebanyak $85 \%$ status nelayan sudah beralih menjadi pedagang (membantu berdagang), pemandu wisata, dan penyewa perahu.

Hal lain yang menjadi temuan penelitian adalah perubahan orientasi berpikir dan kehidupan nelayan dari orientasi laut ke orientasi darat. Hal 
tersebut ternyata menjadi bentuk “streotif" yang dibentuk pada keluarga dan generasi berikutnya. Para nelayan generasi pertama dan kedua merasakan dan mengalami langsung kekurangan secara ekonomi, tidak sejahtera dan terlalu banyak resiko negatif menggantungkan hidup dari laut.

Gambaran umum temuan penelitian tersebut menjadi salah satu akar penyebab munculnya ketidak pedulian dan ketidak respekan masyarakat pulan terhadap pentingnya pendidikan kelautan diberikan pada generasi mereka. Terdapat suatu kecenderungan pada keluarga muda (generasi ketiga dan keempat) menganggap laut menjadi wilayah yang harus dihindari atau dijauhi oleh anak-anak karena bisa membahayakan keselamatan mereka. Dari keseluruhan kegiatan di masyarakat pulau Untungjawa belum ditemukan kegiatan yang mengarah pada pembinaan generasi warga pulau tentang pentingnya pendidikan kelautan, baik terstruktur maupun tidak terstruktur.

Berdasarkan studi analilsis kebutuhan, hasil wawanacara lapangan, warga masyarakat pulau, penelitian juga menemukan bahwa sekolah (khususnya SD Negeri) belum memiliki kurikulum dan pembelajaran yang mengakomodasi kebutuhan, kekuatan dan kelemahan kondisi geografis dimana sekolah tersebut berada.

Sejalan dengan konsep diversifikasi kurikulum yang diamanahkan undang-undang, khususnya kebijakan tentang KTSP (Kurikulum Tingkat Satuan Pendidikan). Kebijakan ini seharusnya menjadi pintu masuk bagi satuan pendidikan untuk menghadirkan kurikulum dan pembelajaran yang sesuai dengan kondisi dan kebutuhan geografis sekolah. Selain itu, hasil studi khusus yang dilakukan di sekolah (SD) menemukan beberapa fakta sebagai berikut:

(1) pengalaman melaksanakan pendidikan kelautan

Dari 9 guru yang mengisi angket hanya 1 yang belum pernah memberi pendidikan kelautan. Ini menunjukkan bahwa sebagian besar guru di SD Negeri pulau Untung Jawa (90\%) pernah melaksanakan pendidikan kelautan. Pengalaman dapat menjadi modal kekuatan untuk secara sadar merekonstruksi ulang kurikulum dan pendidikan kelautan bagi siswa di SD. 
(2) Komponen konten pendidikan kelautan.

Pada aspek ini dapat diperoleh informasi pendapat guru tentang konten pendidikan kelautan yang dianggap penting adalah :

a. Kehidupan dasar laut.

b. Kelestarian alam sekitar laut,

c. Pemberdayaan sumber daya alam kepulauan,

d. Gejala alam yang ada di laut ( Abrasi, tsunami, dsb),

e. Penanaman hutan bakau,

f. Dampak wilayah kepulauan terhadap perilaku hidup masyarakat,

g. Perilaku masyarakat kepulauan,

h. Ekosistem kehidupan laut,

\section{(3) derajat urgensi pendidikan} kelautan,

Berdasarkan informasi ini, guru menyampaikan pendapatnya bahwa sangat perlu $(66,7 \%)$ pendidikan kelautan diberikan pada siswa di SD yang ada di wilayah laut dan sisanya $33,3 \%$ menganggap perlu. Dengan demikian, secara keseluruhan guru menganggap penting dan sangat penting pendidikan kelautan diberikan di SD Pulau Untung Jawa dan SD kepulauan pada umumnya. Pendapat ini menjadi sumber utama bagi pelaksanaan pendidikan kelautan di SD.

\section{(4) Bagian kurikulum pendidikan kelautan}

Pada bagian ini terdapat 7 guru memberikan komentar tentang bagian kurikulum yang perlu dirancang dan diterapkan dalam pendidikan kelautan yakni (1) tema-tema kelautan, (2) kompetensi dan isi mata pelajaran, (3) Pendekatan dan metode dalam proses pembelajaran, (4) Bahan ajar dan buku paket dan (5) metode dan laporan penilaian kompetensi. Selain itu, ada pendapat tambahan yang sangat penting disampaikan guru adalah (6) alat peraga atau media pembelajaran tentang kelautan. Dari 9 guru, terdapat dua guru yang tidak memberikan pendapat dan hanya memberikan komentar "prasarananya masih sangat terbatas".

Data atau informasi tersebut memberikan gambaran bahwa guru secara sadar memiliki pemahaman, harapan dan keinginan untuk memperoleh kurikulum dan pendidikan kelautan secara lengkap yang akan dijadikan bahan pembelajaran bagi pada siswanya.

\section{(5) Pentingnya Guru Meguasai Struktur Kurikulum Pendidikan Kelautan}

Berdasarka informasi dari pertanyaan tersebut terdapat $100 \%$ guru menyatakan bahwa guru sangat perlu $(66,7 \%)$ dan perlu $(33,3 \%)$ menguasai kurikulum pendidikan kelautan. Informasi dari pertanyaan ini memperkuat tentang urgensi dan esensi pendidikan kelautan perlu dirancang dan dikuasai guru untuk diimplementasi pada siswanya di SD.

\begin{tabular}{|l|}
\hline \multicolumn{2}{|c|}{ (6) Prioritas Metode Pendidikan } \\
Kelautan. \\
\hline Berdasarkan pendapat guru dari \\
informasi pada pertanyaan ini, guru \\
memberikan urutan prioritas metode \\
dalam memahami dann melaksanakan \\
pendidikan kelautaan adalah : \\
a. Pelatihan : $100 \%$ \\
menghendaki adanya pelatihan \\
b. Worshop : $22,2 \%$ guru \\
memilih workshop \\
\hline
\end{tabular}




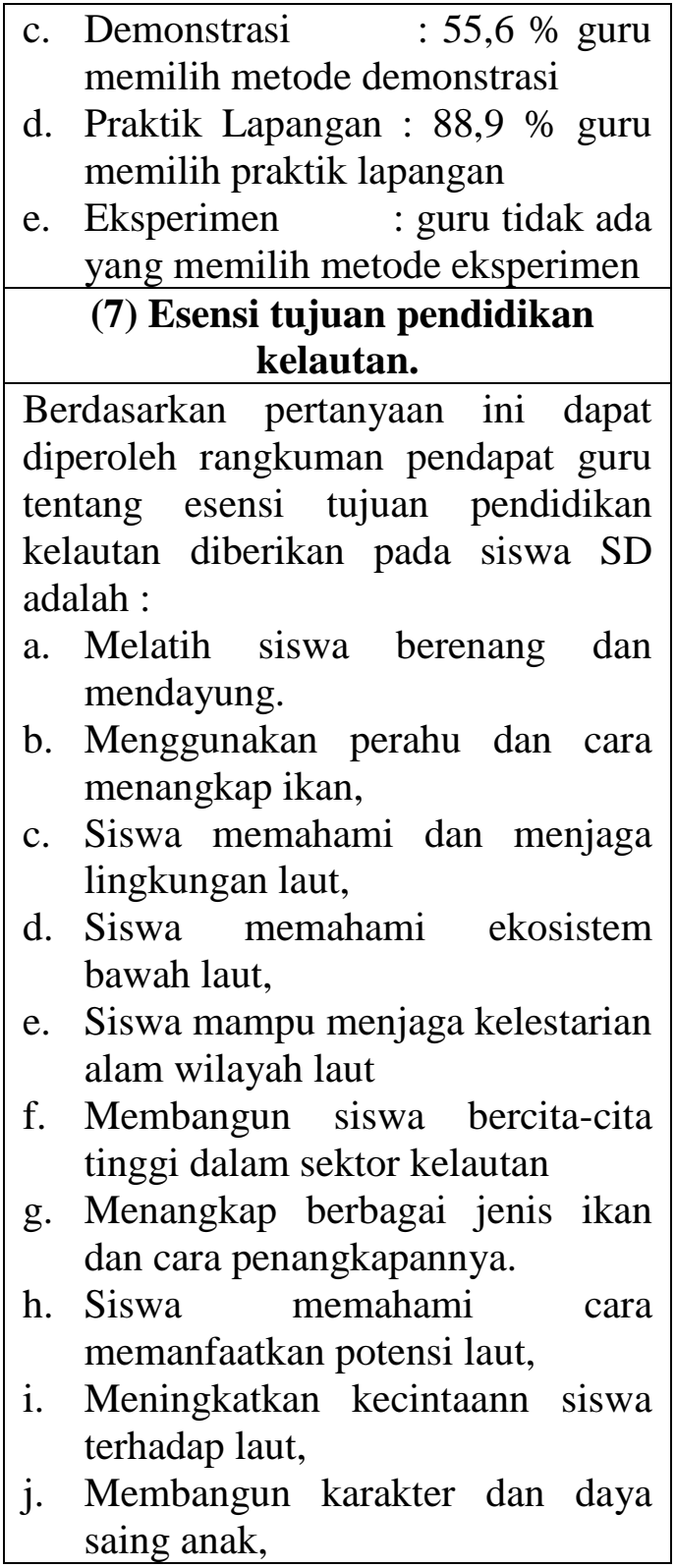

Model pembelajaran tematik integratif berbasis proyek didisain untuk mengakomodasi kebutuhan guru dalam melaksanakan pembelajaran tematik integratif pada kurikulum 2013. Adapun penggunaan pembelajaran proyek dimaksudkan memudahkan guru dalam memahami serta melaksanakan pendekatan saintifik secara utuh dengan lebih terfokus pada pemecahan masalah.

$$
\text { Model PTIBP merupakan suatu }
$$
konsep yang menggambarkan tentang proses pembelajaran yang disajikan dalam bentuk tema dengan mengintegrasikan konten dan tujuan pembelajaran pada dua atau lebih mata pelajaran yang didasarkan pada alur pembelajaran proyek. Model pembelajaran tematik integratif berbasis proyek atau PTIBP merupakan bentuk model konseptual dan prosedural yang dijadikan pijakan dalam menerapkan pendidikan kelautan. Secara konseptual, draft model pembelajaran tematik integratif berbasis proyek dapat digambarkan sebagai berikut :

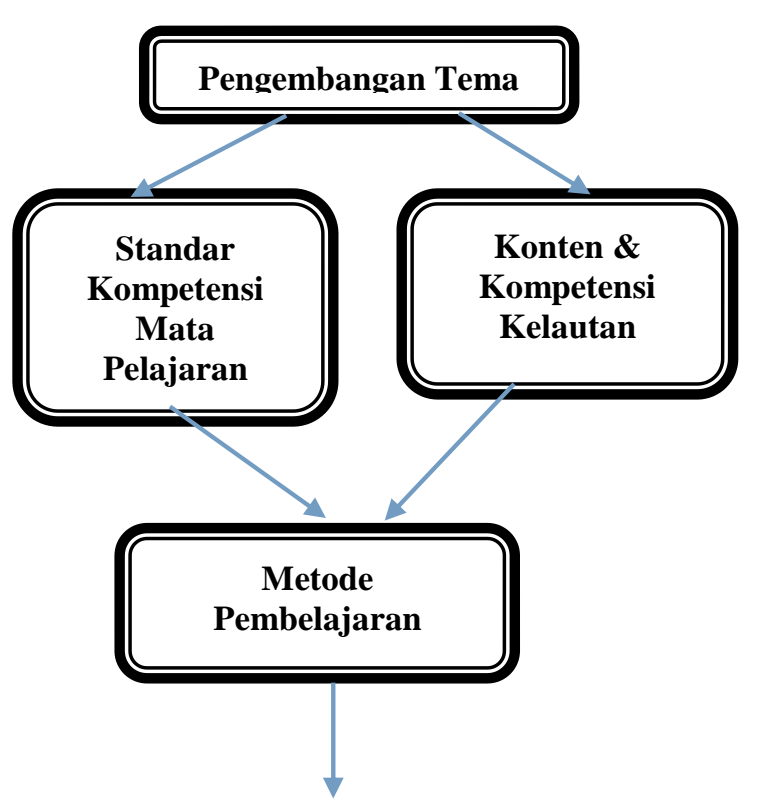




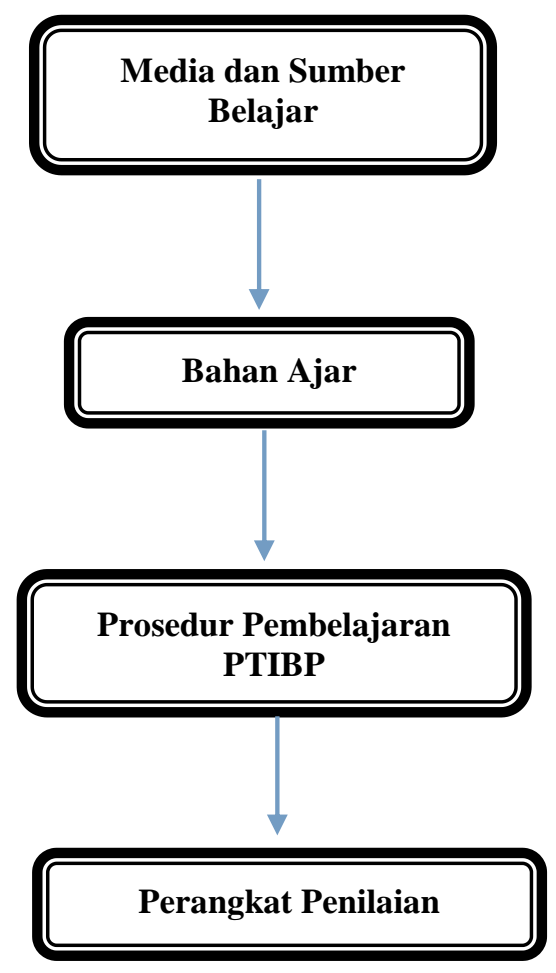

Gambar Konsep Pengembangan Model PTIBP

Berdasarkan gambaran konsep tersebut pengembangan model pembelajaran tematik berbasis proyek (PTIBP) dalam menerapkan pendidikan kelautan dimulai dengan (1) pemilihan dan pengembangan tema. Pemilihan tema dapat dilakukan dengan memodifikasi tema-tema yang dipergunakan dalam kurikulum 2013.

Modifikasi dapat diterapkan dengan memasukan atau mewarnai tema-tema yang ada dengan tema atau topik kelautan, misalnya tema "diri sendiri” dapat dimodifikasi menjadi tema "Aku anak pulau". Selain memodifikasi, pemilihan dan pengembangan tema dapat dilakukan dengan menyusun daftar makhluk hidup, tanaman, binatang, benda dan berbagai peristiwa yang dekat, dilakukan, diamati, dipikirkan dan dirasakan langsung oleh anak. Berdasarkan alur tersebut, pemilihan tema dapat tersusun menjadi tema diri sendiri (aku), makanan, minuman, keluarga, keselamatan dan perlindungan diri, tanaman, binatang, alat tranportasi, gejala alam di pulau, dan seterusnya.

Langkah kedua adalah (2) pemilihan kompetensi mata pelajaran dan antar mata pelajaran. Pada langkah ini, guru dapat menelaah dan mengadaptasi kompetensi mata pelajaran yang dapat dilaksanakan serta dicapai dengan menggunakan tema yang dipilih. Pada langkah ini, guru akan dapat menyusun dan memetakan capaian kompetensi dalam satu semester sesuai dengan tema yang akan dilaksanakan dalam pembelajaran satu semester. 
Susunan kompetensi dalam suatu tema akan membentuk struktur jaringan kompetensi mata pelajaran dan lintas mata pelajaran yang akan membentuk suatu kesatuan capaian kompetensi yang utuh dan komprehensif. Jaringan kompetensi mata pelajaran dan antar mata pelajaran dapat digambarkan dengan ilsutrasi bagai sebagai berikut :

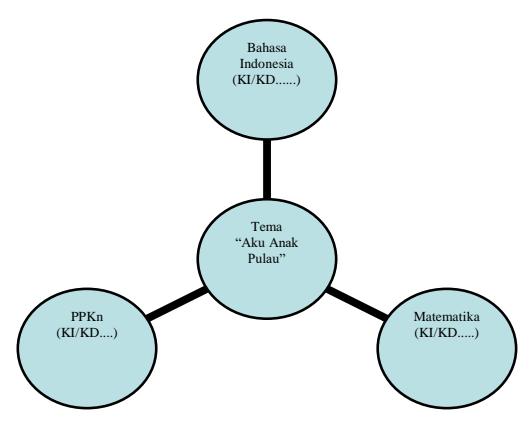

Bersamaan dengan langkah kedua, guru secara simultan dapat menyusun jaringan kompetensi dan konten pendidikan kelautan yang akan ditargetkan untuk dicapai pada suatu tema tertentu.

Kompetensi dan konten pendidikan kelautan dapat diadaptasi dengan standar sains untuk level SD dan/atau menyesuaikan dengan standar kompetensi mata pelajaran yang dimodifikasi ke arah standar kompetensi dan isi pendidikan kelautan untuk tingkat SD.

$$
\text { Sebagai ilustrasi dapat }
$$
diberikan gambaran sebagai berikut:

\begin{tabular}{|c|c|}
\hline $\begin{array}{c}\text { Standar } \\
\text { Kompetensi Mata } \\
\text { Pelajaran }\end{array}$ & $\begin{array}{c}\text { Standar } \\
\text { Kompetensi } \\
\text { Pendidikan } \\
\text { Kelautan }\end{array}$ \\
\hline \begin{tabular}{lr}
\multicolumn{2}{l}{ Menunjukkan } \\
perilaku & teliti dan \\
peduli & dengan \\
menata & benda- \\
benda di & sekitar \\
ruang & kelas \\
berdasarkan & \\
dimensi & (bangun \\
datar, bangun & buang), beratnya, \\
atau & urutan \\
kelompok terkecil & tampai terbesar. \\
\end{tabular} & $\begin{array}{l}\text { Menunjukkan } \\
\text { perilaku teliti dan } \\
\text { peduli terhadap } \\
\text { gejala atau tanda } \\
\text { bahaya } \\
\text { kerusakan atau yang } \\
\text { terjadi di pantai } \\
\text { atau di laut. }\end{array}$ \\
\hline \begin{tabular}{lr}
\multicolumn{2}{l}{ Menerima } \\
keberagaman \\
karakteristik \\
individu & dalam \\
kehidupan & \\
beragama & sebagai \\
anugerah & Tuhan \\
Yang Maha & Esa di \\
lingkungan & rumah \\
dan sekolah &
\end{tabular} & $\begin{array}{l}\text { Menerima } \\
\text { keberagaman } \\
\text { karakteristik warga } \\
\text { masyarakat pulau } \\
\text { dalam hal agama, } \\
\text { suku, dan adat } \\
\text { istiadat. }\end{array}$ \\
\hline
\end{tabular}

\begin{tabular}{|c|c|}
\hline $\begin{array}{l}\text { Tema-tema } \\
\text { Kelautan }\end{array}$ & $\begin{array}{c}\text { Standar } \\
\text { Kompetensi } \\
\text { Pendidikan } \\
\text { Kelautan }\end{array}$ \\
\hline $\begin{array}{ll}\text { Aku Anak } \\
\text { Pulau }\end{array}$ & $\begin{array}{ll}\text { 1. } & \text { Menunjukkan } \\
& \text { identitas jati diri } \\
& \text { sebagai warga } \\
& \text { masyarakat yang } \\
& \text { hidup di wilayah } \\
\text { kepulauan. } \\
\text { 2. } & \text { Menunjukkan }\end{array}$ \\
\hline
\end{tabular}




\begin{tabular}{|c|c|c|}
\hline & & $\begin{array}{l}\text { keterampilan } \\
\text { perlindungan diri } \\
\text { dari kemungkinan } \\
\text { bahaya dari } \\
\text { kondisi hidup di } \\
\text { wilayah pulau. } \\
\text { Bersikap peduli } \\
\text { dan respek } \\
\text { terhadap berbagai } \\
\text { kejadian di } \\
\text { sekitar pulau } \\
\text { yang dapat } \\
\text { membahayakan } \\
\text { diri sendiri dan } \\
\text { orang lain. }\end{array}$ \\
\hline Keluarga & & $\begin{array}{l}\text { Memberikan } \\
\text { gambaran asal } \\
\text { usul keluarga } \\
\text { yang mendiami } \\
\text { dan hidup di } \\
\text { wilayah pulau. } \\
\text { Menunjukkan } \\
\text { kebiasaan yang } \\
\text { dilakukan oleh } \\
\text { kelarga yang } \\
\text { hidup di wilayah } \\
\text { kepulauan. }\end{array}$ \\
\hline
\end{tabular}

Pada langkah berikutnya, secara konseptual guru dapat (4) memilih metode pembelajaran yang sesuai dengan kebutuhan pencapaian kompetensi dan tema yang dipergunakan.

Guru dapat memilih metodemetode pembelajaran yang sesuai dengan prinsip pembelajaran sebagaimana yang rekomendasikan dalam prinsip pembelajaran dalam K-13, diantaranya prinsip aktif, kreatif, inovatif, bermakna dan menyenangkan. Langkah ini dapat menjadi pijakan untuk (5) memilih dan mengembangkan media dan sumber belajar yang sesuai dengan tujuan dan kompetensi yang akan dicapai. Pemilihan media dan sumber belajar yang direkomendasikan sesuai dengan kondisi lingkungan belajar siswa yang berada di wilayah kepulauan.

Pada langkah keenam, guru selanjutnya dapat mulai merancang dan mengembangkan bahan ajar sendiri berdasarkan kebutuhan pencapaian kompetensi dan indikatornya, khususnya dalam pencapaian kompetensi yang sejalan dengan pendidikan kelautan.

Langkah ini dapat dilakukan sejalan dengan upaya guru melakukan elaborasi berbagai referensi yang menunjang pencapaian kompetensi dalam bidang pendidikan kelautan untuk sekolah dasar. Bahan ajar perlu dirancang secara fungsional praktis yang memudahkan siswa mempelajari berbagai konten bidang kelautan yang sekaligus 
membantu mencapai penguasaan kompetensi mata pelajaran.

Langkah ketujuh, guru dapat mengakhiri model ini secara konseptual dengan memilih dan mengembangkan rancanangan penilaian proses dan hasil belajar siswa yang sesuai dengan kompetensi dan konten pendidikan kelautan.

Dari aspek prosedural, model pembelajaran tematik integratif berbasis proyek akan memberikan gambaran tentang prosedur dan uraianya secara lebih rinci. Prosedur pembelajaran yang dimaksud dapat dijelaskan sebagai berikut :

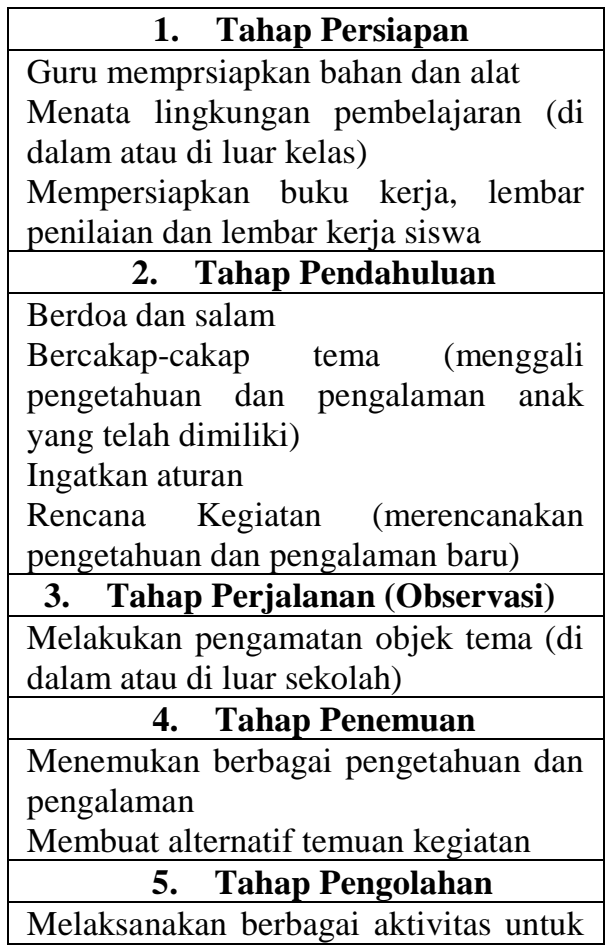

\begin{tabular}{|l|}
\hline $\begin{array}{l}\text { menghasilkan pengetahuan dan } \\
\text { pengalaman baru }\end{array}$ \\
\hline \multicolumn{2}{|c|}{ Tahap Penyajian } \\
\hline $\begin{array}{l}\text { Mempresentasikan pengetahuan dan } \\
\text { pengalaman yang diperoleh }\end{array}$ \\
\hline \multicolumn{2}{|c|}{ Tahap Pendisplay } \\
\hline Menyusun dislay karya \\
\hline
\end{tabular}

\begin{tabular}{|c|}
\hline Contoh Penerapan Prosedur PTIBP \\
\hline 1. Tahap Persiapan \\
\hline Tema : Aku dan Teman \\
\hline $\begin{array}{l}\text { Kegiatan Belajar } 1 \text { : Bermain membuat } \\
\text { kartu nama }\end{array}$ \\
\hline $\begin{array}{l}\text { Kegiatan Belajar } 2 \text { : Bernyanyi dan } \\
\text { menjawab pertanyaan dalam lagu. }\end{array}$ \\
\hline $\begin{array}{l}\text { Kegiatan Belajar } 3 \text { : Bermain membuat } \\
\text { denah posisi tempat duduk }\end{array}$ \\
\hline 2. Tahap Pendahuluan \\
\hline Berdoa dan salam \\
\hline $\begin{array}{l}\text { Bercakap-cakap tentang identitas diri } \\
\text { dan teman }\end{array}$ \\
\hline Tanya jawab aturan di sekolah \\
\hline Mencanakan kegiatan hari in \\
\hline 3. Tahap Perjalanan (Observasi) \\
\hline $\begin{array}{l}\text { Mengamati : proses pembuatan kartu } \\
\text { nama, denah ruangan dan ekspresi lagu }\end{array}$ \\
\hline 4. Tahap Penemuan \\
\hline Menemukan ide kegiatan “ \\
\hline Membuat kartu nama \\
\hline Mndisain denah posisi tempat duduk \\
\hline 5. Tahap Pengolahan \\
\hline $\begin{array}{l}\text { Melaksanakan berbagai aktivitas untuk } \\
\text { menghasilkan pengetahuan dan } \\
\text { pengalaman baru }\end{array}$ \\
\hline 6. Tahap Penyajian \\
\hline $\begin{array}{l}\text { Mempresentasikan pengetahuan dan } \\
\text { pengalaman yang dieroleh }\end{array}$ \\
\hline 7. Tahap Pendisplay \\
\hline
\end{tabular}

Secara konseptual dan prosedural, model pembelajaran tematik integratif berbasis proyek dapat diadaptasi dengan pendekatan saintifik yang dikemas dalam kurikulum 2013 dan pendekatan konstruktivisme dalam kegiatan pembelajaran inti di standar 
proses (Permendiknas No 41 Tahun 20017) yang menggunakan tiga fese yakni eksplorasi, elaborasi dan konfirmasi. Dengan demikian, model ini dapat dipergunakan guru di SD bersamaan dengan pelaksanaan kurikulum 2013, terutama pada standar proses pembelajaran. Model pembelajaran tematik integratif berbasis proyek hanya direkomendasikan untuk SD dengan karakteristik geografis kepulauan dan kelautan. Model ini diharapkan akan dapat dipergunakan secara efektif dalam menerapkan pendidikan kelautan untuk siswa SD kelas awal sebagai bagian akhir dari masa usia dini.

Berdasarkan beberapa temuan penelitian yang telah dipaparkan, model pembelajaran tematik integratif berbasis proyek akan menjadi pilihan model alternatif untuk mengimplementasi kurikulum dan proses pembelajaran pada K-13. Pilihan model ini secara efektif dapat dipergunakan guru untuk melaksanakan pembelajaran lintas mata pelajaran dan menghubungan capaian kompetensi antar mata pelajaran dalam beragam konteks yang nyata, bermakna dan menyenangkan.

Model ini sekaligus membantu menajamkan keterampilan ilmiah siswa melalui pembelajaran proyek yang direncanakan, dilaksanakan dan dievaluasi oleh siswa itu sendiri. Sejalan dengan hal tersebut, secara khusus model ini ditujukan untuk menjadi pilihan alternatif bagi pemerintah dalam melaksanakan pendidikan kelautan pada siswa SD untuk mempersiapkan para siswa memiliki budaya maritim sesuai dengan kekhasan geografis negara Indonesia. Pemerolehan budaya meritim ini akan menjadi modal untuk membangun generasi emas Indonesia 2045 yang mampu mewujudkan Indonesia sebagai poros maritim dunia.

\section{KESIMPULAN}

Penelitian ini menyimpulkan bahwa warga masyarakat dan warga sekolah di SD Negeri Pulau Untungjawa memiliki anggapan bahwa pendidikan kelautan merupakan hal yang urgen diberikan pada siswa SD sebagai generasi yang hidup di daerah kepulauan. Model 
pembelajaran tematik integrative dapat dijadikan alternatif untuk mengimplemtasikan pendidikan kelautan pada siswa SD di wilayah warga kepulauan. Model pembelajaran ini sangat bisa diadaptasi dengan kebijakan pemerintah tentang kurikulum 2013. Model pembelajaran ini juga ramah dengan prinsip dasar pembelajaran yang kontekstual, aktif, kreatif, inovatif dan menyenangkan.

\section{DAFTAR PUSTAKA}

Badan Standar Nasional Pendidikan, (2007), Peraturan Menteri Pendidikan nasional rePublik indonesia Nomor 41 tahun 2007 tentang standar Proses untuk satuan pendidikan dasar dan menengah.

Depdiknas, (2003), Kurikulum Berbasis Kompetensi, Pelayanan Profesional Kurikulum 2004.

Irene, Childa., (2013). Implementasi Pembelajan Tematik pada Siswa Kelas Rendah di SD Negeri Balekerto, Magelang.

Kemenristekdikti, (2017), Rencana Induk Riset Nasional Tahun 20172045, (di unduh dari http://simlitabmas.ristekdikti.go.id lunduh_berkas/RENCANA\%20I NDUK\%20RISET\%20NASIONA L\%20TAHUN\%202017$2045 \% 20 \% 20-$ $\%$ 20Edisi\%2028\%20Pebruari\%20 2017.pdf)
Nani Suryani, dkk., (2004). Analisis Pendidikan Formal Anak pada Keluarga Nelayan di Desa Karangjaladri, Kecamatan Parigi, Kabupaten Ciamis, Jawa Barat. Buletin Ekonomi Perikanan, Volume V, No.2

Pusat Data kependudukan Kelurahan Untung Jawa, pelayanan Publik,https://sipp.menpan.go.id/p elayanan_publik/wilayah/pemerin tah-provinsi-jakarta/pemerintahkab-kepulauan-seribu/pemerintahkecamatan-kepulauan-seribuselatan/pemerintah-kelurahanpulau-untung-jawa

Saleh, Haji (2009). Dampak Penerapan Pendekatan Tematik dalam Pembelajaran Matematika di Sekolah Dasar. Jurnal Pendidikan, Volume 10, Nomor 1

Stepart, D., (2007). Neanderthal children and their flints. $\mathrm{Pal} /$ Arch's journal of Archaelogy of Northwest Europe 1 (2).

Sukini., (2012). Pembelajaran Tematik di Sekolah Dasar Kelas Rendah dan Pelaksanaannya. Jurnal Magistra, Nomor 82, Tahun XXIV.

Sulistiani, Wiwik dan Arya, Lutfi, Model Pembelajaran Tematik Berbasis Kelautan dan Kemaritiman pada anak usia dini di PAUD Nonformal. PENDIDIKAN YANG MENUMBUHKAN INSAN PEMBELAJAR ISBN: 978-979-315384-1 